\title{
Methodology for Studying the Ecological Quality of Furniture
}

\section{Metodologija proučavanja ekološke kvalitete namještaja}

\author{
Original scientific paper • Izvorni znanstveni rad \\ Received-prispjelo: 23. 11. 2010. \\ Accepted-prihvaćeno: 27. 4. 2011. \\ UDK: 630*79; 630*836; 674.23 \\ doi:10.5552/drind.2011.1038
}

\begin{abstract}
Decisions for environment-friendly production and environmentally acceptable products are becoming a necessity and one of very important objectives of timber companies next to already existing economic criteria. Individual products and their manufacture have different influences on the pollution of the environment. Therefore it is necessary to determine the ecological quality of individual products, which means analyzing their ecological suitability during their life cycle. In our research we developed the methodology for establishing the ecological quality of furniture, based on three scientific methods: the method of life cycle analysis, ABC analysis, modified for our case, and the multi-criteria decision-making method. We analyzed the ecological quality of three kitchens of a well-known manufacturer. The results of the research are the basis for developing an optimal business strategy from the viewpoint of determining a production assortment. The used methodology is also suitable for studying other furniture products and for accepting optimal environmentally acceptable decisions in wood companies.
\end{abstract}

Key words: wood company, furniture, ecological quality, methodology, decision-making

SAŽETAK • Odabir ekološke proizvodnje i ekološki prihvatljivih proizvoda, osim već postojećih ekonomskih kriterija, postaju nužnost i jedan od vrlo važnih ciljeva drvnoprerađivačkih tvrtki. Pojedini proizvodi i njihova proizvodnja imaju različite utjecaje na onečišćenje okoliša. Stoga je potrebno utvrditi ekološku kvalitetu pojedinih proizvoda, što znači analizirati njihove ekološke pogodnosti tijekom njihova životnog ciklusa. U ovom je istraživanju utemeljena metodologija utvrđivanja ekološke kvalitete namještaja, koja se temelji na tri znanstvene metode: metodi životnog ciklusa proizvoda, ABC analizi koja je modificirana za tu metodologiju i na metodi multikriterijskog odlučivanja. Analizirana je ekološka kvaliteta triju kuhinja poznatog proizvođača. Rezultati istraživanja osnova su za izgradnju optimalne poslovne strategije sa stajališta određivanja proizvodnog asortimana. Metodologija kojom smo se koristili također je pogodna za proučavanje ostalih vrsta namještaja i za donošenje optimalnih ekološki prihvatljivih odluka u drvnim poduzećima.

Ključne riječi: drvnoindustrijsko poduzeće, namještaj, ekološka kvaliteta, metodologija, odlučivanje

\footnotetext{
Authors are associate professor and assistant at Biotechnical Faculty, University of Ljubljana, Ljubljana, Slovenia.

${ }^{1}$ Autori su izvanredni profesor i asistent Biotehničkog fakulteta Sveučilišta u Ljubljani, Ljubljana, Slovenija.
} 


\section{INTRODUCTION}

\section{UVOD}

Global market, which requires and encourages constant progress, is more and more demanding when it comes to environment protection regulation. Also the market of financial capital, which is more and more favorable towards environmental projects, demands for a restructuration of wood industry in accordance with environmental needs. Many authors (Paluš and Matova, 2009; Kaputa and Šupin, 2010; Kuzman et al., 2010) have dealt with these problems.

Ecological awareness of manufacturers is nowadays an important competitive advantage, which the company can acquire in foreign or home markets (Oblak and Tratnik, 1997). Wood industry basically processes environment friendly natural material - wood, but the technological procedures, materials, use of products and their disposal are ecologically challenging. Therefore, ecological quality of the products in individual phases of their life cycle must be determined from their conception, use of resources, production, use, until the disposal of "used" products (Winter et al., 1993).

The objective of our research was to determine the ecological quality of three kitchens from a wellknown manufacturer. On the basis of the results, the company could adopt a long-term strategy, where one of the most important goals would be to develop and produce products from environment friendly materials, with low use of all kinds of energy and with low emissions of harmful matters into earth, water and air.

\section{METHODS AND MATERIALS 2. METODE I MATERIJALI}

Ecological problems are so complex that they need to be solved systematically (Oblak and Kropivšek, 1997). For this purpose we used three scientific-research methods in the research:

- the method of life cycle analysis,

- modified ABC analysis and

- the multi-criteria decision-making method.

Despite the fact that there are various methods for studying the ecological quality of products, we decided for an innovative approach and with the combination of the above methods we developed a methodology that later showed to be very suitable for decisionmaking in wood companies, aimed at making environment friendly decisions.

\subsection{The method of life cycle analysis}

2.1. Metoda životnog ciklusa proizvoda

The method of life cycle analysis is a methodological framework for estimating and assessing the environmental impacts attributable to the life cycle of a product, such as climate change, stratospheric ozone depletion, tropospheric ozone (smog) creation, eutrophication, acidification, toxicological stress on human health and ecosystems, depletion of resources, water use, land use, noise and others.

With the method of life cycle analysis we tried to demonstrate a complete image of possible interactions of production processes with environment. The method helps us to understand long-term consequences of human activity in the environment and in decisionmaking, when opportunities are sought for improving the ecological behavior (Košir, 1999).

This method is used for evaluating the burdening of the environment, connected with manufacturing of products or services, by establishing how much energy and materials are required according to the type and quantity, which types and quantities of waste and of emissions into environment are produced and what are the possible consequences for the environment ( $\mathrm{Ri}$ chter, 1995).

The evaluations include the whole life cycle of the product, together with planning, acquiring raw materials and energy, production, transport and distribution, packaging, use, maintenance, possible recycling and final disposal. This is, therefore, a complex analysis of all factors that can influence the environment; and hence the effects of the emissions are evaluated on the basis of:

- harmful effects on people, animals, plants or ecosystem or other objects, such as buildings or ozone layer

- duration of effects (long life cycle of harmful substances in the environment)

- tendency for spreading or dispersion

- piling up, which is tightly connected with the duration of the effect and can cause elevated local concentrations

- synergic effects with other substances or products produced in the environment

\section{2 $A B C$ analysis}

\section{2. $A B C$ analiza}

When establishing a system of environment protection, a great deal of ecological parameters is met in the company. This demands a large scope of work, but also causes lack of clarity over the whole action. Thorough following and analysis of all ecological parameters would also cause high expenses, surely not in proportion with the results that can be expected from it. It is, therefore, necessary to determine the critical ecological parameters and prioritize them in the procedure (Oblak et al., 1998).

This can be achieved by ABC analysis. It is a very widely applied method that was used for many years only for economic studies, but in this research we modified it also for solving environmental problems in companies. The method is based on Parrett's principle of cause-consequence interdependence, which says that approximately $20 \%$ of causes is responsible for approximately $80 \%$ of consequences or effects. If this is applied to the environmental field, this means that $20 \%$ of ecological parameters cause $80 \%$ of ecological problems in the companies (Ljubič, 2000).

With this method, all ecologic parameters are categorized in three typical groups. Group A is for 5-10\% of ecological parameters that are responsible for the major share (70-80\%) of environment pollution, group $\mathrm{C}$ consists of the major share of less important ecologi- 
cal parameters $(60-70 \%)$ that cause only a minor, less important pollution share $(5-10 \%)$, while the middle group B consist of $20-30 \%$ of ecological parameters that influence the pollution with a $10-25 \%$ share (Oblak and Podlesnik, 2005).

For the needs of our research, the method was slightly modified by adding two intermediate groups $\mathrm{AB}$ and $\mathrm{BC}$. Thus, groups $\mathrm{A}$ and $\mathrm{AB}$ will contain the effects on the environment that demand immediate action, groups B and BC will contain the noticeable effects to be resolved in middle terms, and group $\mathrm{C}$ will contain the effects that are of secondary importance and do not cause any significant damage to the environment.

\subsection{The multi-criteria decision-making method 2.3. Metoda multikriterijskog odlučivanja}

The method of multi-criteria decision-making is used for resolving demanding decision-making problems. The essence of this method is to break the decision-making problem to smaller units and treat them separately. The variants are deconstructed to individual parameters and evaluated separately. By merging these evaluations a final grade is obtained, which is the basis for selection of most suitable variant (Rajkovič and Bohanec, 1995).

Definition of the problem is followed by determination and implementation of the list of criteria considered important. For the needs of the model, the criteria must be hierarchically organized while considering inter-dependences and content connections. This way a tree of criteria is obtained. A measuring scale and estimating value is attributed to each criterion, which can be used for evaluation. With the help of a program package for decision-making support, the utility functions and decision-making (if-then) rules are defined. On the basis of these functions the computer determines the best of all the variants, which are previously described by the values of basic criteria (Jereb et al., 2003)

For a decision-making model, it is necessary to establish a decision-making group, in which experts for the fields involved should be included, as this is the only way to assure greater reliability of the decisionmaking model. The members of the group participate in defining the objectives and demands as well as in setting criteria and decision-making rules, and in the final phase they also help with evaluation and deciding on optimal variant (Novak, 2006).

\section{RESULTS AND DISCUSSION}

\section{REZULTATI I RASPRAVA}

A wood company that produces kitchens was included in the research. After agreement with professional cooperators, we selected three kitchens from their production program. The kitchens differ significantly in the selection of used materials and type of manufacture. For all three kitchens, we analyzed the typical composition: one high sideboard, three low sideboards and two hanging cabinets.

In the first part of the analysis of ecological quality of the kitchens, we used the method of life cycle

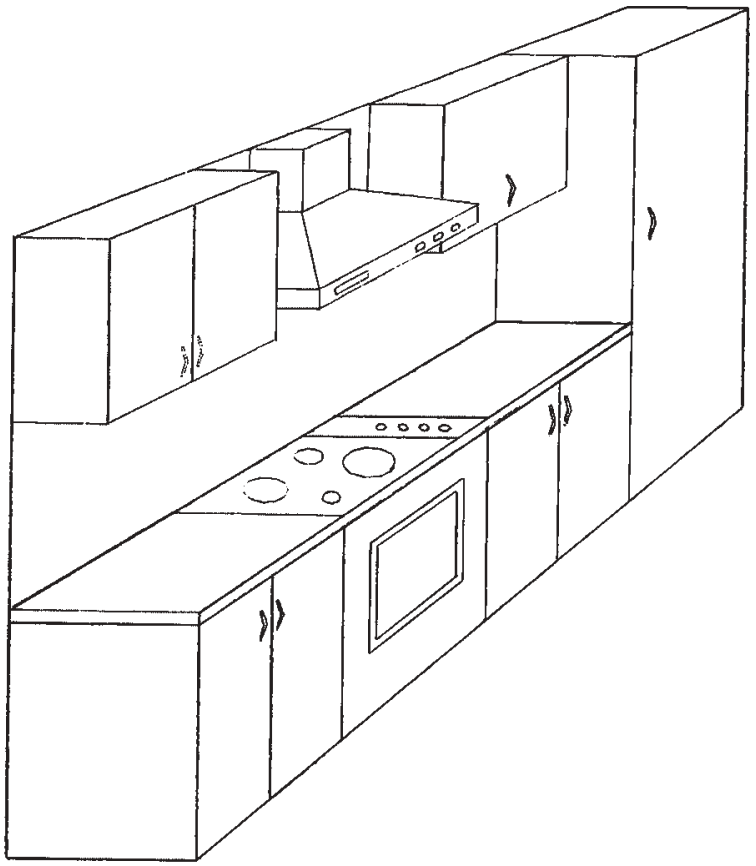

Figure 1 Drawing of studied elements in the kitchens Slika 1. Skica elemenata promatranih kuhinja

analysis. When the life cycle of the products is estimated, the current condition in the company must be analyzed first. In this analysis it is necessary to establish the quantities of raw materials, materials, energy and other substances entering the production process, and the quantities of production emissions into water, air and soil.

We acquired the information on some most important parameters that influence the evaluation of ecological suitability of individual kitchens in the company and this is the subject of this research. Where the data could not be defined in numbers, we used expert evaluations. From the acquired data, a basis of input information was created for the evaluation of ecological quality of the three kitchens during their life cycle. The data are presented in Table 1 and Table 2.

In Table 1 and Table 2, the sign »-« means that a certain substance is not used or consumed for this product, and sign »? « means that no information could be obtained for a certain ecological parameter.

In the second part of the analysis of ecological quality of kitchens, the ABC analysis was used. The analysis was modified for the research needs by introducing two additional classes ( $\mathrm{AB}$ and $\mathrm{BC})$ next to three classical ones (A, B and C). For individual ecological parameters, an expert inter-disciplinary group, formed especially for this assignment, determined the weight or so-called ponders. For raw materials, materials, energies and other substances that make part of the production products, the focus was on the additional materials, such as mastic, bark-liquor, varnishes, glues, solvents, foils and grinding paper. For emissions that are generated in the production process and go into soil, water and air, the most weight was given to waste waters, which present a big problem in wood industry due to the above mentioned materials. 
Table 1 Input information for the analysis of ecological quality of kitchens: Quantity of raw materials, energy and other substances entering the production process

Tablica 1. Unos podataka za analizu ekološke kvalitete kuhinja: količina sirovina, energije i drugih tvari koje ulaze u proizvodni proces

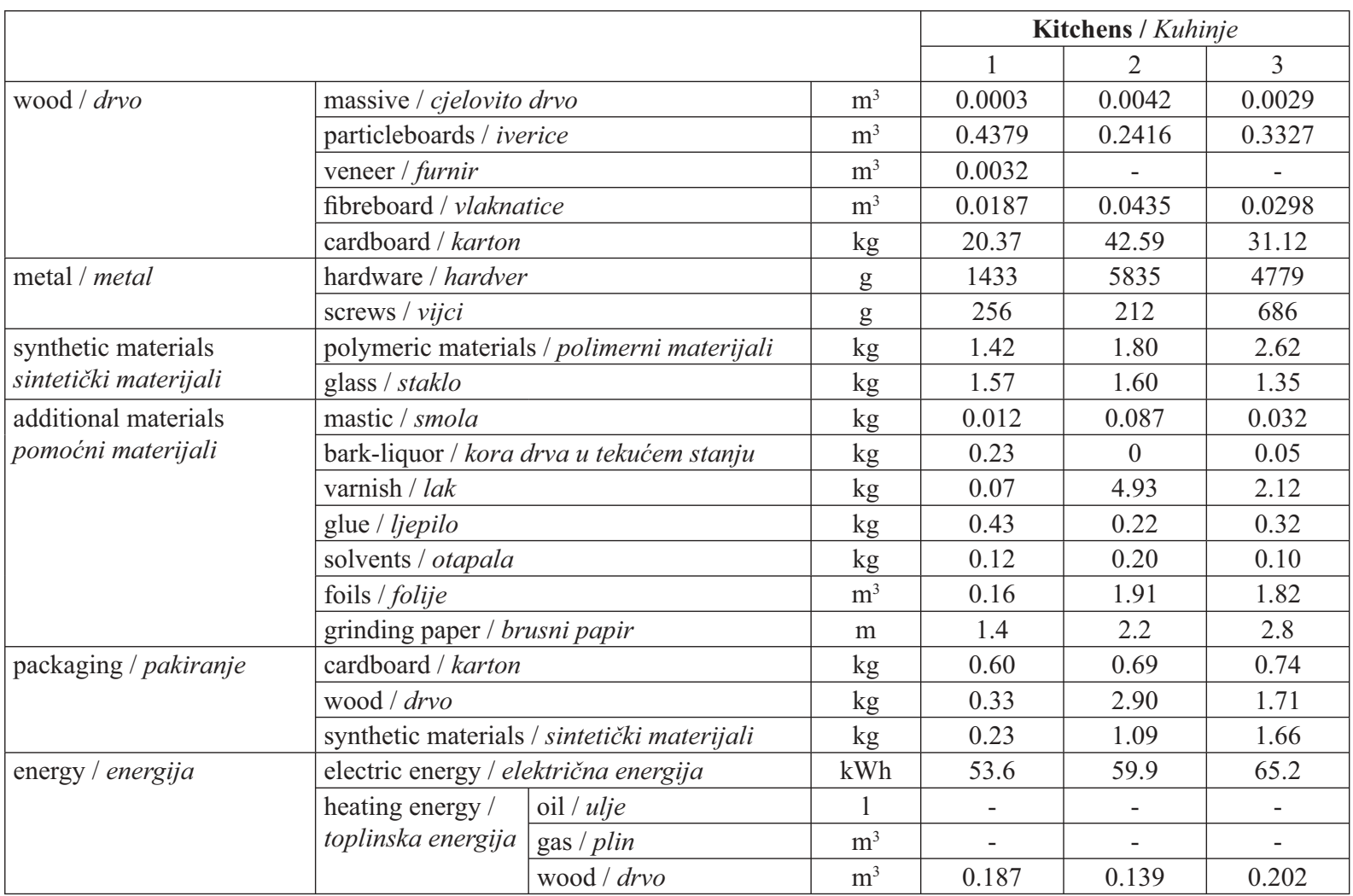

The six members of interdisciplinary expert group placed the ecological parameters into groups $\mathrm{A}, \mathrm{AB}, \mathrm{B}$, $\mathrm{BC}$ and $\mathrm{C}$. They considered the permitted limit values for the ecological parameters specified by applicable regulations and standards. For other ecological parameters decisions were based on intuition. Intuition can help decision makers, especially when they deal with non-standard situations or in expedient decision making.

The evaluations of modified ABC analysis are shown in Table 3.

The third part of the analysis involved the implementation of multi-criteria decision-making model. In our case, the considered variants were three kitchens. First it was necessary to determine the criteria for decisions and implement a decision-making tree. In the structure of the tree, we included all ecological parameters from Table 3. This way we obtained a decisionmaking tree, presented in Figure 2.

The modified groups that we used for ABC analysis were also used for estimating the values. Then decision-making (if-then) rules were established. The developed model was inserted into the computer program DEXi, where the solution was obtained as presented in Figure 3.

The results show that in final evaluation the kitchens were given different values. From the aspect of ecological quality, "kitchen 1" is the most suitable and on the basis of the research results it can be graded as ecologically acceptable. It is followed by "kitchen 3", which is ecologically questionable, and "kitchen 2 " got the worst results and was estimated as ecologically problematic.

On the basis of the obtained results, the company can reconsider the use of certain materials and raw materials and the general assortment of products in the future. A strategic decision would be to stop producing "kitchen 2" and modify the procedures for making "kitchen 3 " in order to improve its ecological quality.

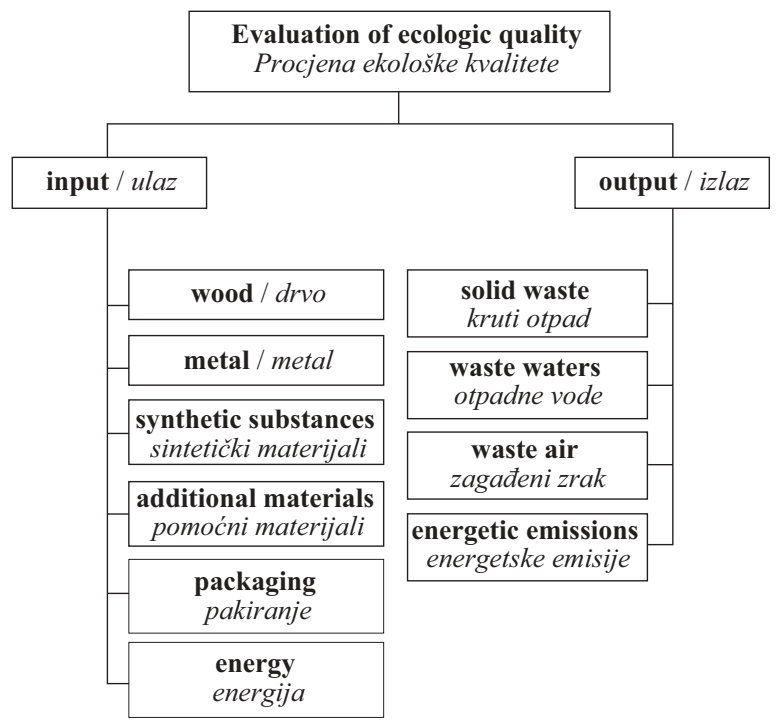

Figure 2 Decision-making tree for multiple criteria decision-making

Slika 2. Drvo odlučivanja pri multikriterijskom odlučivanju 
Table 2 Input information for the analysis of ecological quality of kitchens: Quantities of production emissions into water, soil and air

Tablica 2. Unos podataka za analizu ekološke kvalitete kuhinja: količina emisija koje izlaze iz procesa proizvodnje i koje ulaze u vodu, tlo i zrak

\begin{tabular}{|c|c|c|c|c|c|}
\hline & \multicolumn{3}{|c|}{ Kitchens / Kuhinje } \\
\hline & & & 1 & 2 & 3 \\
\hline \multicolumn{2}{|l|}{ solid waste / kruti otpad } & $\mathrm{m}^{3}$ & 0.18 & 0.03 & 0.09 \\
\hline \multirow[t]{2}{*}{ waste waters / otpadne vode } & sanitary / sanitarne & $\mathrm{m}^{3}$ & 0.07 & 0.09 & 0.10 \\
\hline & industrial / industrijske & $\mathrm{m}^{3}$ & 0.08 & 0.12 & 0.07 \\
\hline \multirow[t]{6}{*}{ waste air / onečišćeni zrak } & $\mathrm{CO}_{2}$ & $\mathrm{mg} / \mathrm{h}$ & $?$ & $?$ & $?$ \\
\hline & $\mathrm{CO}$ & $\mathrm{mg} / \mathrm{m}^{3}$ & 489 & 600 & 560 \\
\hline & $\mathrm{SO}_{2}$ & $\mathrm{mg} / \mathrm{m}^{3}$ & $?$ & $?$ & $?$ \\
\hline & $\mathrm{NO}_{\mathrm{x}}$ & $\mathrm{mg} / \mathrm{m}^{3}$ & 95 & 120 & 250 \\
\hline & $\mathrm{HC}$ & $\mathrm{g}$ & 290 & 420 & 320 \\
\hline & steam / para & $\mathrm{mg} / \mathrm{m}^{3}$ & 15 & 20 & 15 \\
\hline \multirow[t]{2}{*}{ energy emissions / energetske emisije } & noise / buka & $\mathrm{dB}$ & 44 & 53 & 45 \\
\hline & waste heat / izgubljena toplina & MW & 1.0 & 0.7 & 0.4 \\
\hline
\end{tabular}

Table $3 \mathrm{ABC}$ analysis of three kitchens from the aspect of their ecological quality

Tablica 3. ABC analiza triju kuhinja sa stajališta njihove ekološke kakvoće

\begin{tabular}{|c|c|c|c|c|}
\hline \multirow[t]{2}{*}{ Ecological parameters / Ekološki parametri } & \multirow{2}{*}{$\begin{array}{c}\text { Ponder } \\
\%\end{array}$} & \multicolumn{3}{|c|}{ Kitchens / Kuhinje } \\
\hline & & 1 & 2 & 3 \\
\hline $\begin{array}{l}\text { Quantity of raw materials, materials, energy and other substances that enter into the } \\
\text { production process / Količina sirovina, energije } i \text { drugih tvari koje ulaze u proizvodni proces }\end{array}$ & 50 & & & \\
\hline wood / drvo & 3 & $\mathrm{BC}^{*}$ & B & B \\
\hline metal / metal & 3 & $\mathrm{C}$ & $\mathrm{B}$ & $\mathrm{B}$ \\
\hline synthetic substances / sintetički materijali & 12 & $\mathrm{BC}$ & B & $\mathrm{AB}$ \\
\hline additional materials / pomoćni materijali & 20 & $\mathrm{BC}$ & $\mathrm{AB}$ & $\mathrm{B}$ \\
\hline packaging / pakiranje & 2 & $\mathrm{C}$ & B & $\mathrm{BC}$ \\
\hline energy / energija & 10 & $\mathrm{C}$ & $\mathrm{C}$ & $\mathrm{C}$ \\
\hline $\begin{array}{l}\text { Quantities of production emissions into water, soil and air } \\
\text { Količina emisija, koje izlaze iz procesa proizvodnje i ulaze } u \text { vodu, tlo i zrak }\end{array}$ & 50 & & & \\
\hline solid waste / kruti otpad & 5 & $\mathrm{BC}$ & $\mathrm{C}$ & $\mathrm{C}$ \\
\hline waste waters / otpadne vode & 20 & $\mathrm{~B}$ & $\mathrm{AB}$ & $\mathrm{B}$ \\
\hline waste air / onečišćeni zrak & 15 & $\mathrm{~B}$ & $\mathrm{AB}$ & $\mathrm{AB}$ \\
\hline energy emissions / energetske emisije & 10 & $\mathrm{C}$ & $\mathrm{BC}$ & $\mathrm{C}$ \\
\hline
\end{tabular}

*The meaning of class marks in Table is as follows: $\mathrm{A}$ - ecologically unacceptable, $\mathrm{AB}$ - ecologically problematic, $\mathrm{B}$ - ecologically questionable, BC - ecologically acceptable, C - ecologically irreproachable, / Oznake u tablici označavaju: A - ekološki neprihvatjivo, AB - ekološki problematično, B-ekološki upitno, BC-ekološki prihvatljivo, $C$ - ekološki besprijekorno.

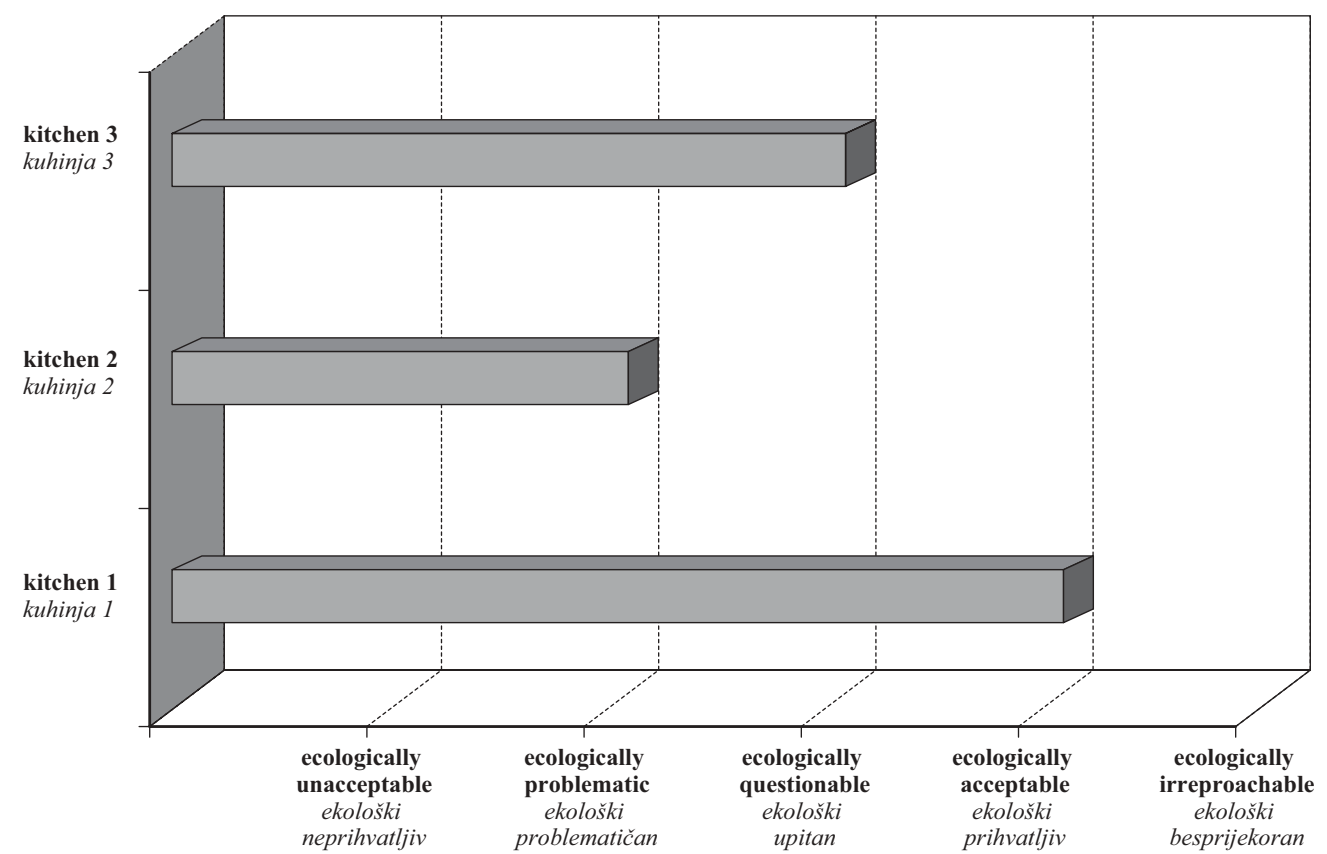

Figure 3 Results of research on ecological quality of three kitchens

Slika 3. Rezultati istraživanja ekološke kvalitete triju kuhinja 


\section{CONCLUSION}

\section{ZAKLJUČAK}

In the research, we analyzed the ecological quality of three kitchens from a well known manufacturer. We implemented a methodology based on three scientific methods: the method of life cycle analysis, $\mathrm{ABC}$ analysis, modified for our case, and the multi- decision-making method. The results of the research have shown that, for the same manufacturer, there are great differences from the aspect of ecological quality in their production and sales program. The three studied kitchens are burdening the environment very differently during their life cycle. The company can profit from the results of this research and use them in order to improve their competitive advantages on the demanding global market.

On the basis of the results of studying the ecological quality of timber products, the products or groups of products that meet the environmental requirements should be marked with a suitable ecological label in the future. This way the customers would know that such a product is more environment friendly in comparison with other products, which can be one of the decisive criteria for selection and purchase for ecologically aware customers.

The used methodology presents an innovative approach to solving ecological problems in companies and is a basis for adopting optimal strategic decisions, connected with ecological quality of the products. In our case, it was used for the evaluation of kitchens, but it is also suitable for the analysis of other products.

\section{REFERENCES}

\section{LITERATURA}

1. Jereb, E.; Bohanec, M.; Rajkovič, V., 2003: Dexi: računalniški program za večparametrsko odločanje: uporabniški priročnik: Kranj, Moderna organizacija.

2. Kaputa, V.; Šupin, M., 2010: Consumer preferences for furniture. In Wood processing and furniture manufacturing: present conditions, opportunities and new challenges: proceedings: Vyhne, Slovakia 2010. Zvolen: Technical University in Zvolen: 81-90.

3. Košir, B., 1999: Ocena življenjskega kroga proizvodov v gozdarstvu. Zbornik gozdarstva in lesarstva, 59: 8-120.

4. Kuzman, K. M.; Medved, S.; Vratuša, S., 2010: Evaluation of Slovenian Contemporary timber construction. Drewno, 53, 183: 85-99.

5. Ljubič, T., 2000: Planiranje in vodenje proizvodnje : modeli, metode, podatki:. Kranj, Moderna organizacija.
6. Novak, B., 2006: Ravnanje z zalogami v lesnem podjetju. Doctoral dissertation: Ljubljana, Biotehniška fakulteta.

7. Oblak, L.; Kropivšek, J., 1997: Ecological Strategy - a Market Opportunity for Slovenian Wood Industry Firms. In: VIII Interchair Meeting of Organisers and Economists in Wood Industry, Stubičke Toplice, Maj, 1997. State and Development Trends in Wood Industry. Zagreb, IACEOWI: 111-116.

8. Oblak, L.; Kropivšek, J; Tratnik, M., 1998: ABC analysis - an aid in structuring and analysing environmental protection problems in timber industry companies. In: Current economic questions in forestry and wood industry / 9th Interchair meeting of economists and organisers in wood industry. - Sopron : Department of Forestry Policy and Economics University of Sopron: 201-206.

9. Oblak, L.; Podlesnik, B., 2005: Nadzor in vodenje zalog $\mathrm{v}$ lesnem podjetju s pomočjo A-B-C in X-Y-Z analize. Les-Wood, 57 (12): 366-370.

10. Oblak, L.; Tratnik, M., 1997: Ecology in Wood Industry - Cost or Strategic Goal. In: Les, drevo, životne prostredie, Zvolen, September, 1997. Kvalita životneho prostredia. Zvolen, Technicka Univerzita vo Zvolene: 111-119.

11. Paluš, H.; Matova, H., 2009: End-user awareness of environmentally appropriate wood products in Slovakia. In: Competitiveness of wood processing and furniture manufacturing, Šibenik, Croatia, 2009. Zagreb : International Association for Economics and Management in Wood Processing and Furniture Manufacturing - WOODEMA, i. a.: $111-116$.

12. Rajkovič, V.; Bohanec, M., 1995: Večparameterski odločitveni modeli. Organizacija, 28, 7: 427-438.

13. Richter, K., 1995: Life cycle analysis of wood products. In LCA - A Challenge for forestry and forest product industry, EFI Proceedings, 8: 65-73.

14. Winter, G.; Ewers, H.J.; Clinton, D.S., 1993: Das umweltbewusste Unternehmen: Handbuch der Betriebsökologie mit 28 Check-Listen für die Praxis: München, Verlag C. H.Beck.

\section{Corresponding address:}

Assoc. Prof. LEON OBLAK, Ph.D.

University of Ljubljana

Biotechnical Faculty

Department of Wood Science and Technology

Rožna dolina, C. VIII/34,

1000 Ljubljana, SLOVENIA

e-mail: leon.oblak@bf.uni-lj.si 